\title{
Leaching of Sulfentrazone in SoIls From the Sugarcane Region IN THE NORTHEAST REgION OF BRAZIL ${ }^{1}$
}

\author{
Lixiviação do Sulfentrazone em Solos da Região Canavieira do Nordeste do Brasil
}

BRAGA, D.F. ${ }^{2}$, FREITAS, F.C.L. ${ }^{3}$, ROCHA, P.R.R. ${ }^{4}$, ARAÚJO, A.G.D. ${ }^{2}$, and MELO, V.C. ${ }^{2}$

\begin{abstract}
Sulfentrazone leaching potential is dependent on soil properties such as strength and type of clay, organic matter content and $\mathrm{pH}$, and may result in ineffectiveness of the product and contamination of groundwater. The objective of this study was to evaluate sulfentrazone leaching in five soils of the sugarcane region in the Northeast Region of Brazil, with different physical and chemical properties, by means of bioassay and high-performance liquid chromatography (HPLC) resolution. The experiment was conducted in a split plot in a completely randomized design. The plots had PVC columns with a $10 \mathrm{~cm}$ diameter and being $50 \mathrm{~cm}$ deep, filled with five different soil classes (quartzarenic neosol, haplic cambisol, yellowish-red latosol, yellowish-red acrisol, and haplic gleysol), and subplots for 10 depths in columns, $5 \mathrm{~cm}$ intervals. On top of the columns, sulfentrazone application was conducted and 12 hours later there was a simulated rainfall of $60 \mathrm{~mm}$. After 72 hours, the columns were horizontally placed and longitudinally open, divided into sections of $5.0 \mathrm{~cm}$. In the center of each section of the columns, soil samples were collected for chromatographic analyses and sorghum sowing was carried out as an indicator plant. The bioassay method was more sensitive to detect the presence of sulfentrazone in an assessment for chromatography soil, having provided greater herbicide mobility in quartzarenic neosol and yellowish-red latosol, whose presence was detected by the indicator plant to a depth of 45 and $35 \mathrm{~cm}$, respectively. In the other soils, sulfentrazone was detected up to $20 \mathrm{~cm}$ deep. The intense mobility of sulfentrazone in quartzarenic neosol may result in herbicide efficiency loss in the soil because the symptoms of intoxication and the amount of herbicide detected via silica were highest between $15 \mathrm{~cm}$ and $35 \mathrm{~cm}$ depth regarding the soil surface layer $(0-10 \mathrm{~cm})$, indicating that sulfentrazone should be avoided in soils with such characteristics.
\end{abstract}

Keywords: herbicide, bioassay, sorption, mobility.

\begin{abstract}
RESUMO - O potencial de lixiviação do sulfentrazone é dependente de atributos do solo, como teor e tipo de argila, teor de matéria orgânica e $\mathrm{pH}$, podendo resultar em ineficácia do produto e contaminação de águas subterrâneas. Objetivou-se neste trabalho avaliar a lixiviação do sulfentrazone em cinco solos da região canavieira do Nordeste do Brasil, com diferentes atributos fisicos e químicos, por meio de bioensaios e cromatografia líquida de alta resolução (CLAE). O experimento foi conduzido no esquema de parcelas subdivididas, no delineamento inteiramente casualizado. As parcelas foram compostas por colunas de PVC com $10 \mathrm{~cm}$ de diâmetro e $50 \mathrm{~cm}$ de profundidade, preenchidas com cinco solos de diferentes classes (Neossolo Quartzarênico, Cambissolo Háplico, Latossolo VermelhoAmarelo, Argissolo Vermelho-Amarelo e Gleissolo Háplico), e as subparcelas, por 10 profundidades nas colunas, com intervalos de $5 \mathrm{~cm}$. No topo das colunas, realizou-se aplicação de sulfentrazone e, 12 horas após, simulou-se uma precipitação pluviométrica de $60 \mathrm{~mm}$. Após 72 horas, as colunas foram colocadas na posição horizontal e abertas longitudinalmente, divididas em seções de $5,0 \mathrm{~cm}$. No centro de cada seção das colunas, coletaram-se amostras de solo para análises cromatográficas e procedeu-se à semeadura de sorgo como planta indicadora. Foi constatada maior mobilidade do herbicida no Neossolo Quartzarênico e no Latossolo Vermelho-Amarelo, cuja presença foi detectada pelas plantas indicadoras até a profundidade de 45 e $35 \mathrm{~cm}$, respectivamente. Nos demais solos, $o$
\end{abstract}

1 Recebido para publicação em 22.4.2015 e aprovado em 24.7.2015.

2 Universidade Federal Rural do Semi-Árido. Mossoró, RN. Brasil, < danielyformiga@ufersa.edu.br>; ${ }^{3}$ Universidade Federal de Viçosa. Viçosa, MG Brasil; ${ }^{4}$ Universidade Federal de Roraima, Boa Vista, RR, Brasil.

Planta Daninha, Viçosa-MG, v. 34, n. 1, p. 161-169, 2016 
sulfentrazone foi detectado até $20 \mathrm{~cm}$ de profundidade. A intensa mobilidade do sulfentrazone no Neossolo Quartzarênico pode resultar em perda de eficiência do herbicida neste solo, pois os sintomas de intoxicação e a concentração de herbicida detectado via cromatografia foram mais elevados entre 15 e $35 \mathrm{~cm}$ de profundidade em relação à camada superficial do solo $(0-10 \mathrm{~cm})$, indicando que o sulfentrazone deve ser evitado em solos com tais caracteristicas.

Palavras-chave: herbicida, bioensaio, sorção, mobilidade.

\section{INTRODUCTION}

Due to intensive use in agriculture, herbicides are often detected in studies about the quality of surface water and groundwater (Carter, 2000; Tanabe et al., 2001). Many of these records are found in areas of sugarcane cultivation, as this is one of the cultures that uses more herbicides in weeds tillage by acreage unit (Southwick et al., 2002).

Leaching is critical for surface incorporation of most herbicides, reaching seeds or plants germinating, but when excessive, can carry them into deeper layers of the soil, limiting its action, and may even promote groundwater contamination (Monquero et al., 2014).

Among the most widely used herbicides in the culture of sugarcane is sulfentrazone 2', 4' -dichloro-5-(4-difluoromethyl-4,5dihydro-3-methyl-5-oxo-1H1,2,4-triazol-1-yl) methanesulfonanilide. This herbicide is an inhibitor of protoporphyrinogen oxidase (PROTOX). According to Rodrigues \& Almeida (2011), it is used in preemergence for the control of dicotyledonous weeds in many monocotyledonous species such as sugarcane. Its half-life in the soil $\left(t_{1 / 2}\right)$ is estimated as being between 110 and 280 days, and its solubility increases with increasing $\mathrm{pH}(\mathrm{pH} 6.0=$ $\left.10 \mathrm{mg} \mathrm{L}^{-1} ; \mathrm{pH} 7.5=1,600 \mathrm{mg} \mathrm{L}^{-1}\right)$. It is considered a weak acid herbicide $(\mathrm{pKa}=6.56)$ and therefore, ionizable, lying in different proportions of its molecular shapes $(\mathrm{pH}<\mathrm{pKa})$ and anionic $(\mathrm{pH}>\mathrm{pKa})$, depending on the medium pH (FMC Corp., 1995).

Several studies have shown that the dynamics of sulfentrazone depends largely on the physical and chemical characteristics of the soil, especially the organic matter content, pH and mineralogy (Passos et al., 2013; Freitas et al., 2014).

Planta Daninha, Viçosa-MG, v. 34, n. 1, p. 161-169, 2016
In Brazil, the land of the Northeast Region they have practically not been studied with regard to herbicides behavior. The soils of the semiarid region have chemical and mineralogical characteristics that are different from those observed in tropical regions because in general they are less weathered, have an alkaline $\mathrm{pH}$, low organic carbon content, and often have a high concentration of salts.

Under these conditions, it is assumed that the risk of sulfentrazone leaching is higher due to the lower adsorption of the herbicide in the soil colloids, which can cause poisoning of crops and soil and water contamination. Freitas et al. (2012) have observed greater ametryn mobility in soils of the semiarid region of the Brazilian state of Rio Grande do Norte, in relation to the yellowish-red latosol of Minas Gerais, influenced by low organic matter content and alkaline $\mathrm{pH}$ of the semiarid region soils.

Herbicides leaching in the field can be monitored by direct sampling of water, soil samples analyses and using lysimeters. However, it has become common to measure the potential for leaching using columns with disturbed soil samples by means of biological and chromatographic assays. These experiments employ humidity and precipitation controlled conditions and enable comparison of different soil classes in a single assay (Freitas et al., 2014; Passos et al., 2015).

Given the above, the aim of this study was to evaluate the leaching of sulfentrazone in five soils of the Northeast Region of Brazil, by means of bioassays and liquid chromatography.

\section{MATERIALS AND METHODS}

The assay was conducted in split plots, distributed in a completely randomized design 
with four replications. The plots consisted of columns filled with five soils collected at $0-20 \mathrm{~cm}$ depth in areas without a herbicide application history: Haplic cambisol - CX (Vale do Jaguaribe - Quixeré, CE); quartzarenic neosol - RQ (coastal region - Pedro Velho, RN), yellowish-red latosol (YRL) and yellowish-red acrisol - PVA (coastal plains - Maceió, AL), and haplic gleysol - GX (floodplain region - Maceió, $\mathrm{AL})$, and the subplots, by 10 layers of depth in the columns, with $5 \mathrm{~cm}$ intervals $(0-5,5-10$, $10-15,15-20,20-25,25-30,30-35,35-40,40-45$ and $45-50 \mathrm{~cm})$.

The soil samples were air dried, earth clods were undone and the samples were passed in $4 \mathrm{~mm}$ mesh sieves. From each soil sample was withdrawn a subsample for carrying out chemical and physical analyses (Tables 1 and 2), according to the methodology described by EMBRAPA (1997), and mineralogical analysis (Table 3), where the separation of the clay fraction of the soils studied was done according to EMBRAPA (1997), besides the identification of minerals, according to Chen (1977).

For soils quartzarenic neosol (RQ), yellowish-red latosol (YRL), yellowish-red acrisol (PVA), and haplic gleysol (GX) liming was performed by the base saturation method in order to adjust the $\mathrm{pH}$, and they were incubated for a period of 30 days, when an analysis was done for reading the new corrected values of the respective index.

The soils were packed in PVC columns of $10 \mathrm{~cm}$ in diameter and $50 \mathrm{~cm}$ long, sectioned every $5 \mathrm{~cm}$ and with a removable side cover, according to the methodology used by Freitas et al. (2012), and subsequently paraffin was internally applied to prevent lateral flow. After filling with soil samples, these were saturated with water for a period of 48 hours and left in the vertical position, resting for 72 hours, in order to drain excess water.

Subsequently, sulfentrazone was applied on top of the columns at a dose of $1 \mathrm{~kg} \mathrm{ha}^{-1}$. Twelve hours after application, the columns still standing upright, a simulated rainfall was provided, with the application of a single $60 \mathrm{~mm}$ water depth for a period of three hours. After the precipitation simulation, the columns were maintained for 72 hours in a
Table 1 - Chemical properties of soils of different sugarcane regions in the Northeast Region of Brazil ${ }^{1 /}$

\begin{tabular}{|l|c|c|c|c|c|}
\hline \multirow{2}{*}{ Soil } & $\mathrm{pH}$ & $\mathrm{CEC}$ & $\mathrm{V}$ & $\mathrm{m}$ & \multirow{2}{*}{ TOC } \\
\cline { 2 - 5 } & $\left(\mathrm{H}_{2} \mathrm{O}\right)$ & $\left(\mathrm{cmol}_{\mathrm{c}} \mathrm{dm}^{-3}\right)$ & $(\%)$ & $\left(\mathrm{g} \mathrm{kg}^{-1}\right)$ & \\
\hline Neosol & 6.7 & 2.19 & 66 & 0 & 5.7 \\
\hline Latosol & 6.0 & 4.70 & 46 & 0 & 13.8 \\
\hline Acrisol & 5.9 & 6.10 & 54 & 4 & 20.6 \\
\hline Gleysol & 5.8 & 9.17 & 60 & 3 & 28.4 \\
\hline Cambisol & 6.7 & 15.4 & 66 & 0 & 15.6 \\
\hline
\end{tabular}

${ }^{1 /}$ Table with results after liming. $(\mathrm{t})=$ effective cation exchange capacity; $\mathrm{V}=$ base saturation; $\mathrm{m}=$ saturation by $\mathrm{Al}^{+3} ; \mathrm{TOC}=$ total organic carbon.

Table 2 - Granulometry analysis of the $0-20 \mathrm{~cm}$ layer of soils of different sugarcane areas of the Northeast Region of Brazil

\begin{tabular}{|l|r|r|r|l|}
\hline \multirow{2}{*}{ Soil } & Sand & \multicolumn{1}{|c|}{ Silt } & Clay & \multirow{2}{*}{ Textural class } \\
\cline { 2 - 4 } & \multicolumn{3}{|c|}{$\left(\mathrm{g} \mathrm{kg}^{-1}\right)$} & \\
\hline Latosol & 630 & 110 & 260 & Franco-Clay-Sandy \\
\hline Acrisol & 680 & 70 & 250 & Franco-Clay-Sandy \\
\hline Gleysol & 500 & 280 & 220 & Franco-silty \\
\hline Neosol & 930 & 50 & 20 & Sand \\
\hline Cambisol & 480 & 150 & 370 & Clay \\
\hline
\end{tabular}

Table 3 - Minerals detected in the clay fraction of the topsoil $(0-20 \mathrm{~cm})$ of the soils studied

\begin{tabular}{|l|l|}
\hline Soil class & Minerals detected \\
\hline Neosol & $\mathrm{Ct} ; \mathrm{Il}-\mathrm{Mi} ; \mathrm{Qz}$ \\
\hline Latosol & $\mathrm{Ct} ; \mathrm{Gb} ; \mathrm{Gt} ; \mathrm{Hm}$ \\
\hline Acrisol & $\mathrm{Ct} ; \mathrm{Gb} ; \mathrm{Gt} ; \mathrm{Hm}$ \\
\hline Gleysol & $\mathrm{Ct} ; \mathrm{Il}-\mathrm{Mi}$ \\
\hline Cambisol & $\mathrm{Ct} ; \mathrm{Gt} ; \mathrm{Hm}$ \\
\hline
\end{tabular}

Ct: kaolinite; Il-Mi: illite-mica; Gb: gibbsite; Gt: goethite; Hm: hematite; Qz: quartz.

vertical position so as to allow water infiltration into the soil; subsequently, they were placed in a horizontal position, when side opening and sectioning every $5 \mathrm{~cm}$ with PVC foil were done.

In the center of each section of the columns, soil samples were collected, which were air dried, earth clods were undone and they were stored in a freezer at a temperature of approximately $-10{ }^{\circ} \mathrm{C}$ for subsequent extraction and quantification of the herbicide by chromatographic analysis. 
After the collection of samples for extraction and determination of the herbicide by chromatography, sowing of five seeds of sorghum (Sorghum bicolor) per segment of the column was carried out in the sections of the columns, as an indicator plant of the sulfentrazone presence.

At 14 days after emergence (DAE) of the indicator species, there was the assessment of herbicide mobility by the indirect (biological) method, evaluating the toxicity index and the accumulation of plant dry matter. In assessing the toxicity index of indicator plants, scores were assigned from 0 (no toxicity) to 100 (plant death). In the evaluation of dry matter, all plants were cut in the soil surface and placed in an oven with forced air circulation $\left(70 \pm 2{ }^{\circ} \mathrm{C}\right)$ to constant weight.

For extraction of sulfentrazone soil samples, the technique of solid-liquid extraction was used, with partition at low temperature, as proposed by Vieira et al. (2007) and Goulart et al. (2008).

The process consisted in measuring a mass of $2.00 \mathrm{~g}$ of dry soil, previously homogenized in screw cap glass flasks with $30.0 \mathrm{~mL}$ of capacity, then adding $12.0 \mathrm{~mL}$ of the extracting mixture consisting of $4.0 \mathrm{~mL}$ of water and $8.0 \mathrm{~mL}$ of acetonitrile. The bottles were subjected to vertical stirring for 30 minutes. Subsequently, the samples were left for \pm 12 hours in a freezer at a temperature of approximately $-20^{\circ} \mathrm{C}$. After this period, there was a common filtration of the unfrozen fraction, organic extract and herbicide, for volumetric flask of $10.0 \mathrm{~mL}$. Fractions containing soil and frozen water were discarded. After reaching room temperature, the filtered solutions were transferred to a round bottom flask with $10.0 \mathrm{~mL}$ of capacity for evaporation of solvent in a rotary evaporator at a temperature of $50 \pm 1^{\circ} \mathrm{C}$. After evaporation, the round bottom flask was washed with three aliquots of $0.50 \mathrm{~mL}$ of acetonitrile, and the final extract was filtered again in a membrane of $0.45 \mu \mathrm{m}$ and stored in vials of $1.5 \mathrm{~mL}$ capacity for subsequent analysis by high-performance liquid chromatography (CLAE).

Sulfentrazone determination was performed using a liquid chromatography system of high efficiency, model Varian ProStar 325, with a UV-Vis detector and a stainless steel column (Varian Microsorb 100 $3 \mathrm{C} 18,100 \mathrm{~mm} \times 4.6 \mathrm{~mm}$ d.i.).

The chromatographic conditions for analysis consisted in a mobile phase of water and acetonitrile at a ratio of 50:50 (v/v), acidified with $0.01 \%$ of phosphoric acid; flow: $1.2 \mathrm{~mL} \mathrm{~min}^{-1}$; injection volume: $20 \mu \mathrm{L}$; column temperature: $30^{\circ} \mathrm{C}$; and wavelength for reading: $214 \mathrm{~nm}$.

The herbicide stock solution was prepared from the standard with $98.3 \%$ purity, at a concentration of 1,000 ig $\mathrm{mL}^{-1}$ in acetonitrile, and the working solutions were prepared therefrom. Quantitation was performed by comparison of the areas obtained on the chromatograms, by the external calibration method.

To interpret the results, the data obtained in the bioassay and in the chromatographic analysis were submitted to analysis of variance and regression analysis. In the choice of the models, biological response, significance of the regression coefficients and coefficients of determination were taken into account.

\section{RESULTS AND DISCUSSION}

The increased mobility of sulfentrazone was found in RQ, being detected by the indicator plants up to a depth of $45 \mathrm{~cm}$, indicating a high potential for herbicide leaching in this soil (Figure 1), which resulted in the reduction of herbicide concentration in the first $10 \mathrm{~cm}$ of the columns, evidenced by the lower toxicity index and higher dry matter accumulation in the indicator plants in relation to the depth of $15-35 \mathrm{~cm}$, where symptoms were most evident.

The transport of the herbicide in the soil, with lower concentrations in the surface layers, compromises its effectiveness in controlling weeds, since almost all the weeds seeds that germinate are located near the soil surface, especially in the first $5 \mathrm{~cm}$ deep.

The high potential for leaching in this soil is due to the sandy texture and low organic matter content (Tables 1 and 2). According to Liu et al. (2010), in soils with little organic matter and little clay, the percolation of herbicides can occur, making them available 
in the soil solution and making it amenable to transportation to the water table.

Rossi et al. (2003), working with columns and using an unstructured quartzarenic neosol, have detected poisoning by
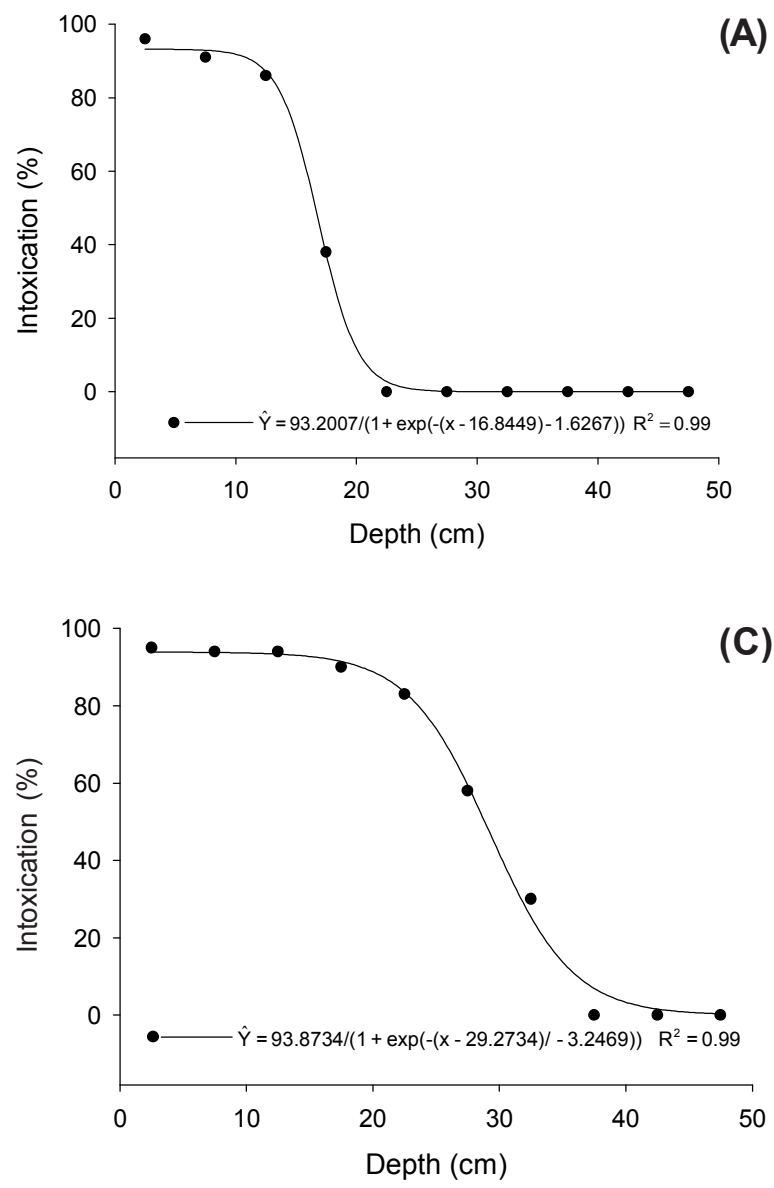

sulfentrazone in the indicator plants at $22.5 \mathrm{~cm}$ and $30 \mathrm{~cm}$ deep, respectively, for water depths of 60 and $90 \mathrm{~mm}$. Therefore, it is assumed in this work that if water depth higher than $60 \mathrm{~mm}$ were applied, herbicide mobility would have been even greater.
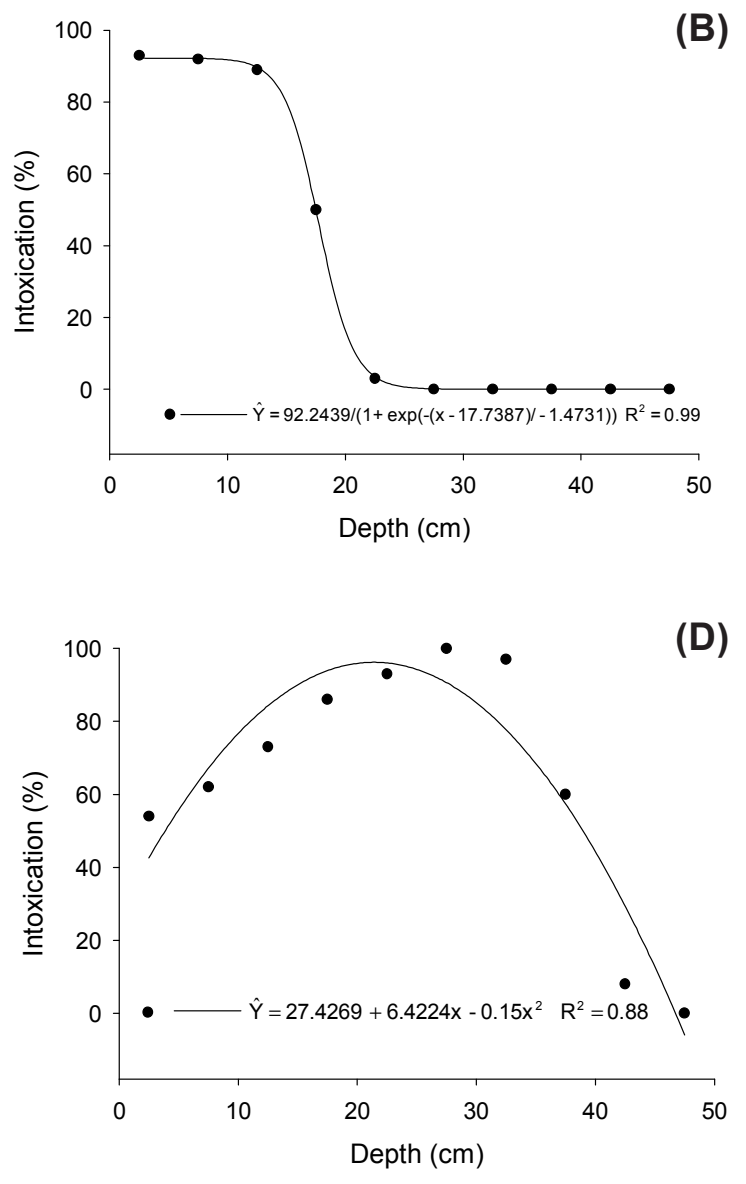

(E)

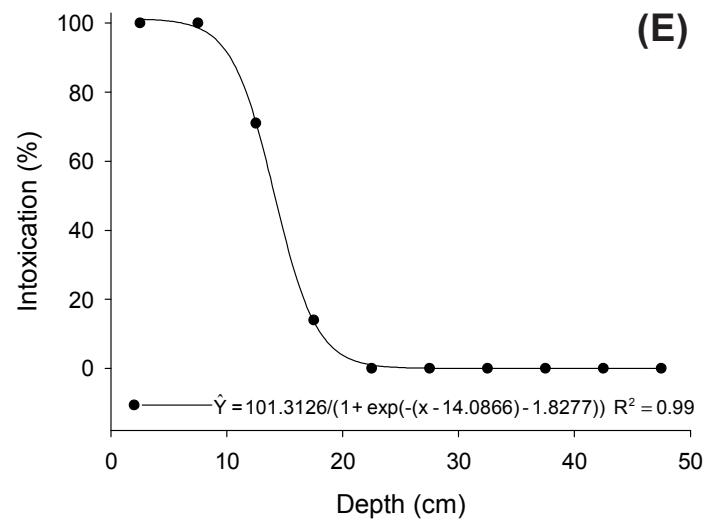

Figure 1 - Intoxication of sorghum plants in the soils in the Northeast Region of Brazil: Acrisol (A), Cambisol (B), Latosol (C), Neosol (D) and Gleysol (E), at different depths from the column after application of sulfentrazone and a $60 \mathrm{~mm}$ rainfall simulation. 
Herbicide mobility was also high on YRL, with symptoms of intoxication and reduced dry matter accumulation in the indicator plants observed to a depth of $35 \mathrm{~cm}$ (Figures 1 and 2C).

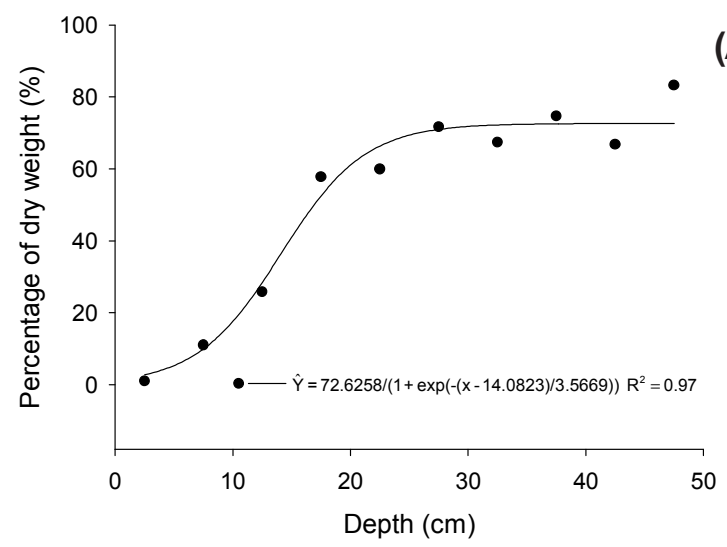

(A)

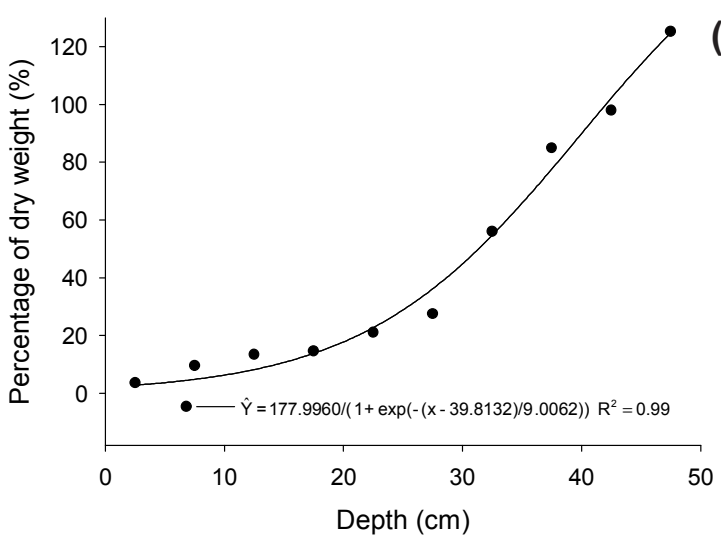

(C)

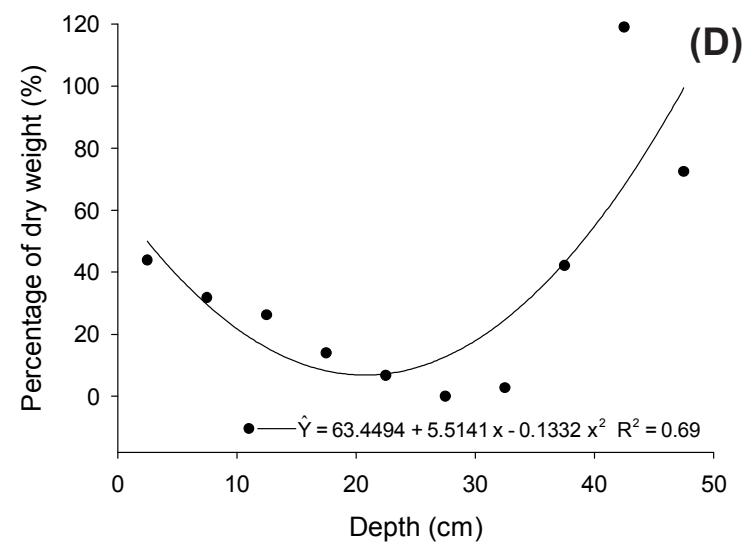

(E)

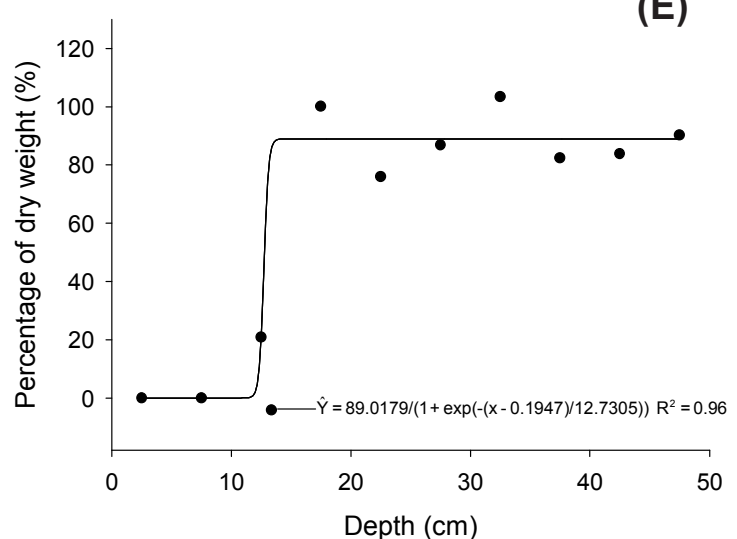

Figure 2 - Percentage of dry matter of sorghum compared to the control at different depths of the columns in the five soils: Acrisol (A), Cambisol (B), Latosol (C), Neosol (D) and Gleysol (E), after applying sulfentrazone and a 60 mm rainfall simulation.

Planta Daninha, Viçosa-MG, v. 34, n. 1, p. 161-169, 2016

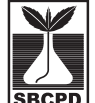


(Gt), and hematite (Hm) (Table 3). Iron oxides (hematite and goethite) and aluminum (mainly gibbsite) exhibit similar behavior to that of clay minerals $1: 1$, which have low CEC (cation-exchange capacity). According to Procópio et al. (2001), in tropical conditions where soils are highly weathered, there are predominantly oxides and hydroxides of iron and aluminum and silicate clays $1: 1$ of low reactivity (kaolinite); thus, organic matter is the primary contributor to these soils CEC. As shown in Table 1 , the low organic matter content of this soil does not favor herbicide retention either.

In many cases, there is no correlation between the herbicide sorption and soil clay content (Grey et al., 1997; Freitas et al., 2012, 2014; Melo et al., 2010). This is because the chemical characteristics of clays depend on the original soil material and its degree of weathering, which vary widely in tropical conditions (Lindsay, 2001).

In YRL, CX and GX, sulfentrazone caused poisoning in the indicator plants up to $20 \mathrm{~cm}$ depth (Figure 1), although with more pronounced symptoms up to $15 \mathrm{~cm}$, indicating a higher concentration of herbicide to this depth, which is enhanced by the reduction in dry matter accumulation, detected for their soils up to $15 \mathrm{~cm}$ (Figures 2A, B and E). Freitas et al. (2012) have also found higher efficiency in visual assessment of indicator plants intoxication in relation to the dry matter accumulation. Sulfentrazone lower mobility seems to be related to the higher content of organic matter for YRL and GX, and clay for $\mathrm{CX}$, increasing herbicide sorption.

Freitas et al. (2012), working with ametryn in soils from different regions (including the Northeast Region of Brazil), have observed leaching of this herbicide up to $20 \mathrm{~cm}$ deep in a cambisol (Apodi, RN) and up to $25 \mathrm{~cm}$ in a latosolic dystrophic yellowish-red acrisol (Mossoró, RN), while in a yellowish-red latosol (Viçosa, MG) the movement of this herbicide was up to $5 \mathrm{~cm}$ deep. These authors claim that the increased mobility in the Northeast Region of Brazil soils was influenced by the physical and chemical characteristics of the soil, such as texture, clay content and organic matter, and can be enhanced in soils with high $\mathrm{pH}$.
The liquid chromatography technique allows the quantification of herbicide content along the soil column, showing its displacement in different segments. Figure 3 shows the concentration of sulfentrazone in different soils in each segment of the column, which shows that the detection of sulfentrazone by means of the chromatographic method was slightly lower than the visual poisoning evaluation in the bioassay (Figures 1 and 2), presenting, however, the advantage of determining the herbicide concentration in the soil profile.

However, when the herbicide is distributed in the soil profile, slight variations can result in difficulty in adjusting models to explain the phenomenon, as shown in (Figure 3D), where it was not possible to adjust any model for the results of the chromatographic method in the quartzarenic neosol.

Chromatography requires sophisticated laboratories and highly skilled labor and consumes large amounts of solvents and other chemical products that can contaminate the environment, whereas the detection by the biological assay is a much simpler and cheaper process, which requires simpler structures, corroborating Melo et al. (2010) and Freitas et al. (2012), who claim that the bioassay joins cost efficiency to good practical results.

However, when the two methods are performed simultaneously, the results are much clearer, with the possibility to observe the biological effect of the herbicide residues and quantify the substance by means of chromatography.

Herbicide mobility in the soil profile can be beneficial to herbicides that exert their effect on seed or seedling during germination or emergence; however, in excess, it can lead to reduced effectiveness by percolation of the compound in the soil profile, besides the possibility of water table contamination.

Passos et al. (2015), working with sulfentrazone in soils collected in reforestation areas, have found that red acrisol with higher clay content, was the soil that retained in the first depths $(0-15 \mathrm{~cm})$ the highest concentration of the herbicide, whereas for haplic planosol, with the lowest content of clay 


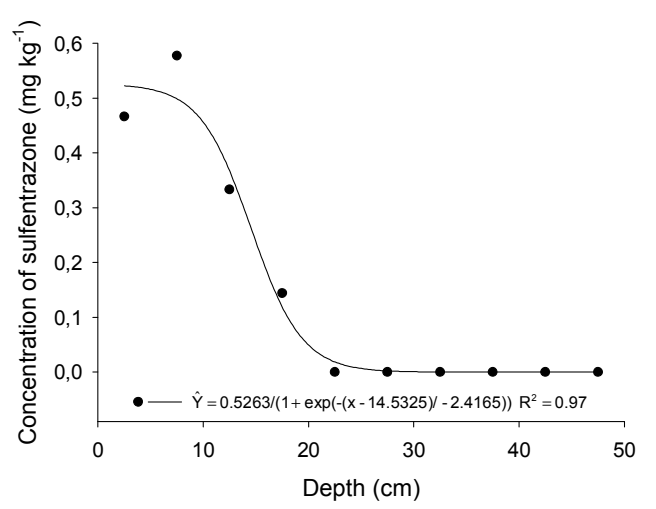

(A)

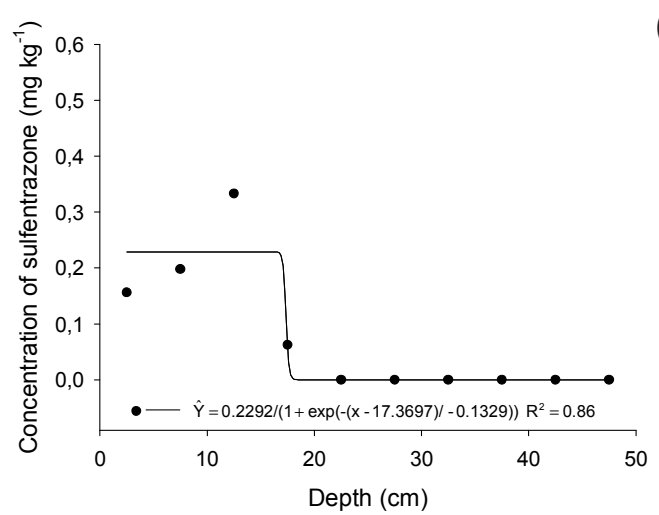

(B)
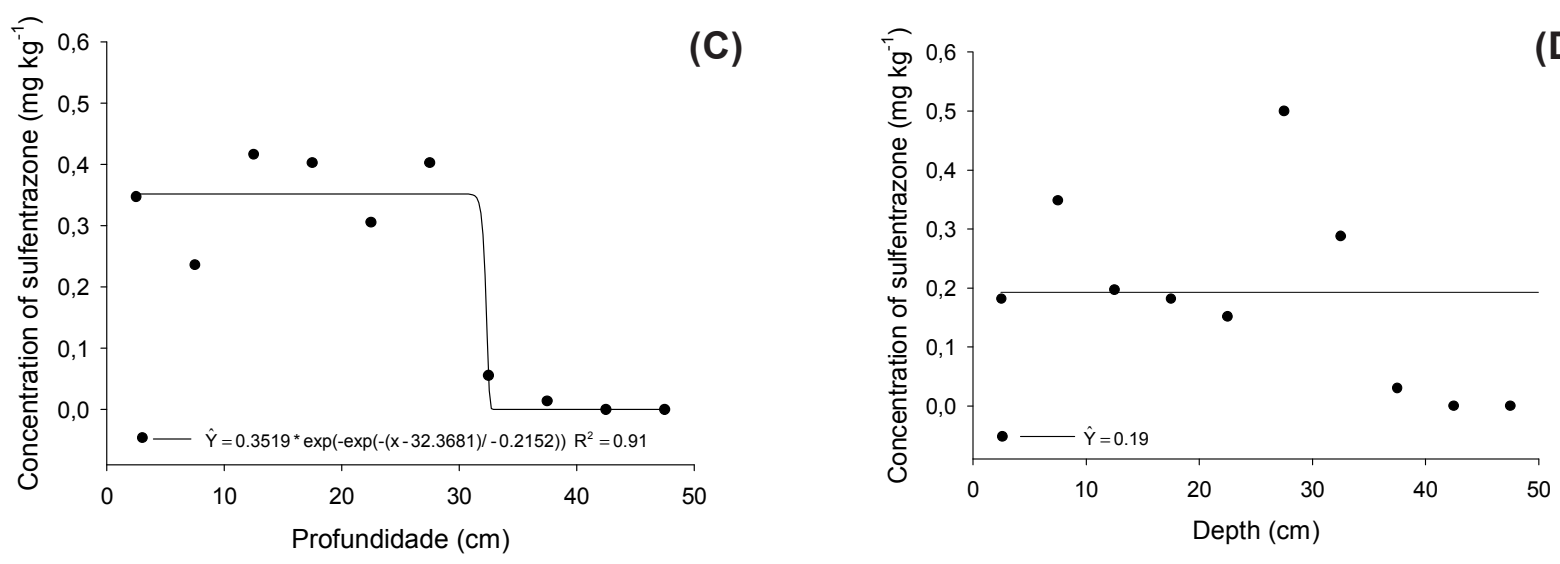

(D)

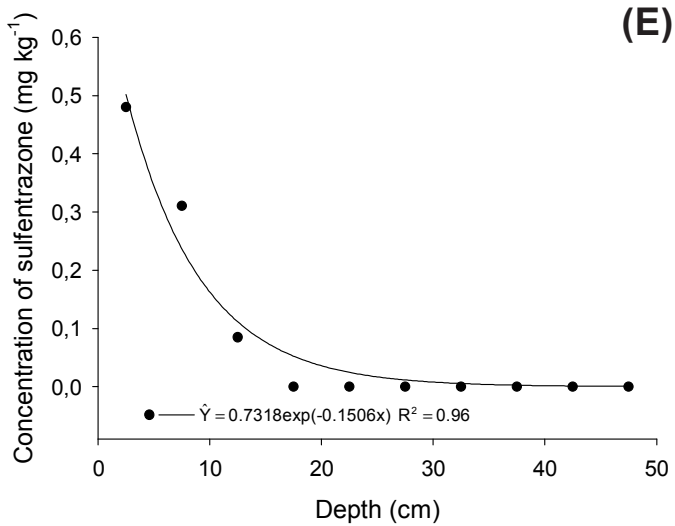

Figure 3 - Sulfentrazone concentrations at different depths of the columns in the five soils: Acrisol (A), Cambisol (B), Latosol (C), Neosol (D) and Gleysol (E), after applying sulfentrazone and a $60 \mathrm{~mm}$ rainfall simulation.

and organic matter, the concentration of sulfentrazone found was almost homogeneous in all sections of the column. This result shows the great influence of clay and organic matter content in sulfentrazone mobility, in accordance with Grey et al. (1997) and Melo et al. (2010).
These results are in agreement with the ones by Freitas et al. (2014), who have found effects of physical and chemical characteristics of soils on sulfentrazone behavior. According to these authors, to recommend this herbicide in order to ensure technical efficiency and environmental 
sustainability, it is necessary to know the chemical and physical characteristics of the soils, as its sorption is greatly influenced by texture, organic matter content and $\mathrm{pH}$ of the soils.

It can be concluded that the greatest leaching rates were found in soils with high levels of sand, and there was sulfentrazone efficiency loss in the quartzarenic neosol because the symptoms of poisoning were highest between 15 and $35 \mathrm{~cm}$ deep. Sulfentrazone poisoning symptoms were found up to $45 \mathrm{~cm}$ in the quartzarenic neosol, $35 \mathrm{~cm}$ in the yellowish-red latosol, $20 \mathrm{~cm}$ in the yellowish-red acrisol, $20 \mathrm{~cm}$ in the haplic cambisol and $20 \mathrm{~cm}$ in the haplic gleysol.

\section{LITERATURE CITED}

CARTER, A. D. Herbicide movement in soils: principles, pathways and processes. Weed Res., v. 40, n. 1, p. 113-122, 2000 .

CHEN, P. Y. Table of key lines in X-ray powder diffraction patterns of minerals in clays and associated rocks: Geological Survey Occasional Paper 21. Bloomington: Indiana Geological Survey Report, 1977. 67 p.

\section{EMPRESA BRASILEIRA DE PESQUISA} AGROPECUÁRIA - EMBRAPA. Manual de métodos de análise de solo. 2. ed. Rio de Janeiro: 1997. 212 p.

FMC Crop. Technical bulletin of sulfentrazone. Philadelphia: 1995.6 p.

FREITAS, M. A. M. et al. Sorção do sulfentrazone em diferentes tipos de solo determinada por bioensaios. Planta Daninha, v. 32, n. 2, p. 385-392, 2014.

FREITAS, F. C. L. et al. Mobilidade do ametryn em solos da região semiárida do Rio Grande do Norte. Planta Daninha, v. 30, n. 3, p. 641-648, 2012.

GOULART, S. M. et al. Low-temperature clean-up method for the determination of pyrethroids in milk using gas chromatography with electron capture detection. Talanta, v. 75, n. 5, p. 1320-1323, 2008.

GREY, T. L. et al. Sulfentrazone adsorption.and mobility as affected by soil and pH. Weed Sci., v. 45, p. 733-738, 1997.
LINDSAY, W. L. Chemical equilibria in soils. New Jersey: Blackburn, 2001. 449 p.

LIU, Y. et al. Adsorption and desorption behavior of herbicide diuron on various Chinese cultivated soils. J. Hazard.

Mater., v. 178, n. 1-3, p. 462-468, 2010.

MELO, C. A. D. et al. Lixiviação de sulfentrazone, isoxaflutole e oxyfluorfen no perfil de três solos.

Planta Daninha, v. 28, n. 2, p. 385-392, 2010.

MONQUERO, P. A. et al. Manejo de Merremia aegyptia com misturas de herbicidas utilizando diferentes lâminas de água e na presença ou ausência de palha de cana-de-açúcar. R. Bras. Herbic., v. 13, n. 2, p. 88-96, 2014.

PASSOS, A. B. R. J. et al. Leaching of sulfentrazone in soils of reforestation in Brazil. Environmental Earth Sciences, v. 74, n. 2, p. 1211-1215, 2015. Disponível em: < http:// link.springer.com/article/10.1007\%2Fs12665-015-4110-7>. Acesso em: 20 set. 2015.

PASSOS, A. B. R. J. et al. Sorption and desorption of sulfentrazone in Brazilian soils. J. Environ. Sci. Health, v. 48, n. 8, p. 646-650, 2013.

PROCÓPIO, S. O. et al. Sorção do herbicida atrazine em complexos organominerais. Planta Daninha, v. 19, n. 3, p. 391-400, 2001.

RODRIGUES, B. N.; ALMEIDA, F. S. Guia de herbicidas. 6. ed. Londrina: 2011. 697 p.

ROSSI, C. V. S. et al. Mobilidade do sulfentrazone em Nitossolo Vermelho e em Neossolo Quartzarênico. Planta Daninha, v. 21, n. 1, p. 111-120, 2003.

SOUTHWICK, L. M. et al. Potential influence of sugarcane cultivation on estuarine water quality of Louisiana's gulf coast. J. Agric. Food Chem., v. 50, n. 15, p. 4393-4399, 2002.

TANABE, A. et al. Seasonal and special studies on pesticides residues in surface eaters of the Shinano river in Japan. J. Agric. Food Chem., v. 49, n. 7, p. 3847-3852, 2001.

VIEIRA, H. P. et al. Otimização e validação da técnica de extração líquidolíquido com partição em baixa temperatura (ELL-PBT) para piretróides em água e análise por CG. Quim. Nova, v. 30, n. 3, p. 535-540, 2007. 